\title{
Group IIa secretory phospholipase expression correlates with group IIa secretory phospholipase inhibition-mediated cell death in K-ras mutant lung cancer cells
}

\author{
Jessica A. Yu, MD, ${ }^{a}$ Howard Li, MD, ${ }^{b}$ Xianzhong Meng, MD, PhD, ${ }^{a}$ David A. Fullerton, MD, ${ }^{a}$ \\ Raphael A. Nemenoff, PhD, ${ }^{\mathrm{c}}$ John D. Mitchell, MD, ${ }^{\mathrm{a}}$ and Michael J. Weyant, MD ${ }^{\mathrm{a}}$
}

\begin{abstract}
Objective: There are currently no targeted therapies against lung tumors with oncogenic K-ras mutations that are found in $25 \%$ to $-40 \%$ of lung cancers and are characterized by their resistance to epidermal growth factor receptor inhibitors. The isozyme group IIa secretory phospholipase $\mathrm{A}_{2}\left(\mathrm{SPLA}_{2} \mathrm{IIa}\right)$ is a potential biomarker and regulator of lung cancer cell invasion; however, the relationship between K-ras mutations and SPLA $_{2} I I a$ has yet to be investigated. We hypothesize that $\mathrm{SPLA}_{2} \mathrm{II}$ a modulates lung cancer cell growth in K-ras mutant cells and that $\mathrm{SPAA}_{2} \mathrm{IIa}$ expression in human lung tumors is increased in K-ras mutant tumors.
\end{abstract}

\begin{abstract}
Methods: Baseline sPLA ${ }_{2} I$ Ia expression in K-ras mutant lung cancer cell lines (A549, SW1573, H358, H2009) was assessed. Cells were treated with a specific $\mathrm{SPLA}_{2}$ IIIa inhibitor and evaluated for apoptosis and cell viability. Nuclear factor kappa-b (NF- $\kappa$ B) and extracellular signal-regulated kinase $1 / 2$ activity were detected by Western blot. Human tumor samples were evaluated for sPLA $_{2}$ IIa mRNA expression by quantitative reversetranscription polymerase chain reaction.
\end{abstract}

Results: Cytotoxicity of $\mathrm{sPLA}_{2} \mathrm{II}$ inhibition correlates with $\mathrm{sPLA}_{2} \mathrm{IIa}$ expression. Apoptosis in response to sPLA $_{2}$ inhibition parallels attenuation in NF- $\kappa$ B activity. In addition, $\mathrm{sPLA}_{2}$ IIa expression in human tumors correlates with squamous cell pathology and increasing stage of K-ras mutant lung tumors.

Conclusions: Baseline sPLA ${ }_{2} \mathrm{IIa}$ expression predicts response to $\mathrm{PLA}_{2} \mathrm{IIa}$ inhibition in some K-ras mutant lung cancer cells. This finding is independent of p53 mutation status. Furthermore, squamous tumors and advancedstage K-ras mutant tumors express more sPLA ${ }_{2} \mathrm{II}$. These data support a role for $\mathrm{sPLA}_{2} \mathrm{IIa}$ as a potential global therapeutic target in the treatment of lung cancer. (J Thorac Cardiovasc Surg 2012;144:1479-85)

Lung cancer remains the most lethal cancer in the world. Gain-of-function mutations in K-ras are found in $25 \%$ to $40 \%$ of lung cancers and are thought to be significant drivers of oncologic virulence. There are currently no targeted therapies that effectively treat K-ras mutant lung tumors. In fact, these mutations are characterized by their resistance to epidermal growth factor receptor (EGFR) inhibitors. ${ }^{1,2}$

Phospholipase $\mathrm{A}_{2}\left(\mathrm{PLA}_{2}\right)$ enzymes release arachidonic acid from cell membranes, initiating downstream production of tumor-promoting eicosanoids. Group IIa secretory phospholipase $\mathrm{A}_{2}$ (sPLA $\mathrm{sPa}_{2}$ ), a subgroup of $\mathrm{PLA}_{2} \mathrm{~s}$, has recently been identified as a potential lung cancer biomarker. ${ }^{3}$

\footnotetext{
From the Division of Cardiothoracic Surgery, ${ }^{\mathrm{a}}$ Department of Surgery, Division of Pulmonary Sciences and Critical Care Medicine, ${ }^{\mathrm{b}}$ and Division of Renal Diseases and Hypertension, ${ }^{\mathrm{c}}$ Department of Medicine, University of Colorado School of Medicine, Aurora, Colo.

Disclosures: Authors have nothing to disclose with regard to commercial support. Read at the 38th Annual Meeting of The Western Thoracic Surgical Association, Maui, Hawaii, June 27-30, 2012.

Received for publication June 25, 2012; revisions received Aug 8, 2012; accepted for publication Aug 23, 2012; available ahead of print Oct 1, 2012.

Address for reprints: Michael J. Weyant, MD, Cardiothoracic Surgery, University of Colorado School of Medicine, 12631 E 17th Ave, C310, Aurora, CO 80045 (E-mail: Michael.Weyant@ucdenver.edu). 0022-5223/\$36.00

Copyright (C) 2012 Published by Elsevier Inc. on behalf of The American Association for Thoracic Surgery

http://dx.doi.org/10.1016/j.jtcvs.2012.08.064
}

In a cohort of patients with solitary pulmonary nodules, patients with lung cancer had higher plasma levels of sPLA $_{2} \mathrm{IIa}$ than patients with a benign nodule. In addition, histologic analysis demonstrates overexpression of sPLA $_{2}$ IIa in lung tumors compared with normal lung tissue. $^{3}$ From a functional perspective, sPLA ${ }_{2}$ IIa has been shown to regulate lung cancer cell growth and invasion. RNA interference of $\mathrm{sPLA}_{2} \mathrm{II}$ decreases tumor growth and nuclear factor kappa-b (NF- $\kappa \mathrm{B})$ activity in a xenograft model of lung cancer. ${ }^{4}$ In addition, sPLA ${ }_{2}$ IIa inhibition decreases intercellular adhesion molecule-1-associated invasion in vitro. ${ }^{5}$

Although cytosolic $\mathrm{PLA}_{2}$ activity is increased in K-ras mutant lung tumors, ${ }^{6-8}$ the relationship between $\mathrm{sPLA}_{2} \mathrm{IIa}$ and $\mathrm{K}$-ras mutant lung cancer has not previously been explored. The aim of this study is to examine the potential of targeted $\mathrm{SPLA}_{2} \mathrm{II}$ a inhibition in K-ras mutant lung cancer. Our purpose was twofold: (1) to investigate the role of $\mathrm{SPLA}_{2} \mathrm{IIa}$ in the growth of $\mathrm{K}$-ras mutant lung cancer cells and (2) to examine sPLA $_{2} \mathrm{IIa}$ expression in human tumor specimens and correlate the results with $\mathrm{K}$-ras mutation status. We hypothesized that $\mathrm{sPLA}_{2} \mathrm{IIa}$ modulates lung cancer cell growth in K-ras mutant cells and that tumor expression of $\mathrm{sPLA}_{2} \mathrm{IIa}$ would correlate with $\mathrm{K}$-ras status and cancer stage. 


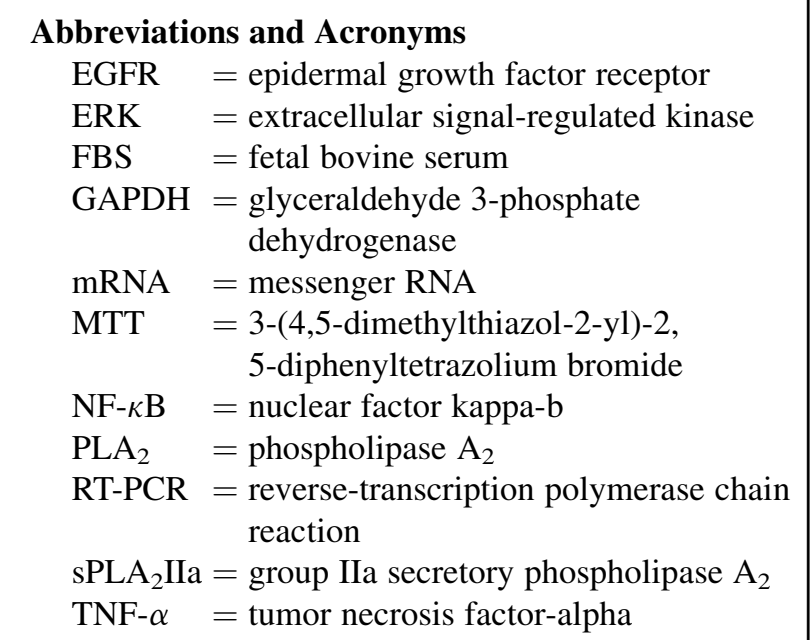

\section{METHODS}

\section{Cells and Reagents}

All cell lines tested were K-ras mutant derived from non-small cell lung cancers (Table 1). A549 cells were a gift from Dr Anirban Banerjee (Aurora, Colo). H358 cells were a gift from Dr Kim O'Neill (Provo, Utah). SW1573 and H2009 were a gift from Dr Mary Reyland (Aurora, Colo). Cells were maintained in a humidified atmosphere with $5 \%$ carbon dioxide using Ham's F-12 (A549) or RPMI media (all other cell lines) with 10\% fetal bovine serum (FBS). Tumor necrosis factor-alpha (TNF- $\alpha$ ) (SigmaAldrich, St Louis, Mo) was used at a concentration of $20 \mathrm{ng} / \mathrm{mL}$ to mimic the inflammatory milieu of the tumor microenvironment. The $\mathrm{SPA}_{2} \mathrm{II}$ inhibitor S3319 (Sigma Aldrich) was dissolved in dimethyl sulfoxide. Dimethyl sulfoxide served as a vehicle control for all experiments with a maximum experimental concentration of $0.08 \%$. Rabbit anti-human antibodies for phosphorylated and total NF- $\kappa \mathrm{B}$ p65, extracellular signalregulated kinase (ERK) 1/2, and glyceraldehyde 3-phosphate dehydrogenase (GAPDH) were obtained from Cell Signaling Technology, Inc (Beverly, Mass). For Western blot, the rabbit anti-human-specific SPLA $_{2}$ IIa antibody was from Abcam (Cambridge, Mass). For immunofluorescence, the rabbit anti-human $\mathrm{SPLA}_{2} \mathrm{II}$ a antibody was obtained from BioVendor, LLC (Candler, NC).

\section{Immunofluorescence Microscopy}

We cultured 5000 cells per chamber on Lab-Tek II 8-well glass chamber slides (Thermo Scientific, Rochester, NY) in full media for 24 hours and then serum-starved them $(0.5 \% \mathrm{FBS})$ for 24 hours. Cells were pretreated with incrementally increasing concentrations of the $\mathrm{SPLA}_{2}$ inhibitor in serum-starved media for 1 hour, then stimulated with $20 \mathrm{ng} / \mathrm{mL}$ TNF- $\alpha$ for 8 hours. Control cells were incubated with dimethyl sulfoxide in serum-starved media and stimulated with TNF- $\alpha$ for 8 hours. Immunofluorescence microscopy was performed to evaluate $\mathrm{SPLA}_{2} \mathrm{II}$ a expression in A549 cells as previously described. ${ }^{9}$

\footnotetext{
Apoptosis Assay

We cultured $1 \times 10^{6}$ cells per well in 12-well plates in full media for 24 hours and then serum-starved them $(0.5 \% \mathrm{FBS})$ for 24 hours before treatment. Cells were treated with sPLA $\mathrm{II}_{2}$ inhibitor $(20$ or $40 \mu \mathrm{mol} / \mathrm{L}$ ) or vehicle control in serum-starved media for 8 hours. A time-response experiment using 4- and 8-hour time points was used to determine the 8-hour time point chosen for this experiment (data not shown). Apoptosis was assessed by flow cytometric detection of annexin $\mathrm{V}$ and propidium iodide (BD Biosciences, San Jose, Calif).
}

\section{Cell Viability Assay}

We cultured $5 \times 10^{3}$ cells per well in 96-well plates in full media for 24 hours and then serum-starved them $(0.5 \%$ FBS $)$ for 24 hours before treatment. Cells were exposed to $\mathrm{SPLA}_{2} \mathrm{II}$ inhibitor $(10-40 \mu \mathrm{mol} / \mathrm{L})$ or vehicle control in serum-starved media for 24 hours. A time-response experiment using 12-, 24-, and 48-hour time points was used to determine the 24-hour time point chosen for this experiment (data not shown). Cell viability was measured with 3-(4,5-dimethylthiazol-2-yl)-2,5-diphenyltetrazolium bromide (MTT) assay according to manufacturer instructions (Roche Applied Science, Indianapolis, Ind)

\section{Western Blot}

Cells were plated on 6-well plates at a density of $3 \times 10^{6}$ in full media for 24 hours, then serum-starved $(0.5 \%$ FBS $)$ for 24 hours, and then treated. Time trials with TNF- $\alpha$ were performed to determine the time of maximal initial increase in phosphorylation of NF- $\kappa$ B and ERK $1 / 2$ in all cell lines. Cells were pretreated with $\mathrm{SPLA}_{2} \mathrm{II}$ inhibitor $(10-40 \mu \mathrm{mol} / \mathrm{L})$ for 1 hour, stimulated with TNF- $\alpha$, then lysed with Laemmli buffer under reducing conditions. In separate experiments, untreated cells were lysed and analyzed for baseline sPLA $\mathrm{SII}_{2}$ expression. Proteins were separated using sodium dodecyl sulfate-polyacrylamide gel electrophoresis techniques and transferred to a nitrocellulose membrane. Membranes were blocked in $5 \%$ nonfat milk in phosphate-buffered saline-Tween. Primary antibodies were dissolved in $5 \%$ bovine serum albumin in phosphate-buffered saline-Tween. Secondary antibodies were prepared in 5\% nonfat milk in phosphate-buffered saline-Tween. The protein of interest was developed using Pierce ECL Chemiluminescent (Thermo Fisher Scientific, Inc, Rockford, Ill). Densitometric analysis was performed using ImageJ Software (National Institutes of Health, Bethesda, Md).

\section{Quantitative Reverse-Transcription Polymerase Chain Reaction (RT-PCR)}

Cells were plated on 12-well plates at a density of $1 \times 10^{6}$ in full media for 24 hours and serum-starved $(0.5 \%$ FBS $)$ for 24 hours before lysis and RNA isolation. RNA was prepared using the Qiagen RNeasy Plus Mini Kit according to the manufacturer's protocol (Germantown, Md). Complementary DNA was synthesized using Bio-Rad iScript (Hercules, Calif). RTPCR was performed using Applied Biosystems Sybr Green Master Mix (Carlsbad, Calif). The primer sequences used are as follows: sPLA $_{2} \mathrm{IIa}$ (forward): CCC-TCC-TAC-TGT-TGG-CAG-TGA-T; sPLA 2 IIa (reverse): CCT-GTC-GTC-AAC-TTG-ATC-ATT-CTG; GAPDH (forward): CCTGCA-CCA-CCA-ACT-GCT-TAG; GAPDH (reverse): TGA-GTC-CTTCCA-CGA-TAC-CAA. Denaturation $\left(95^{\circ} \mathrm{C}, 15\right.$ seconds), annealing $\left(52^{\circ} \mathrm{C}, 30\right.$ seconds), and elongation $\left(72^{\circ} \mathrm{C}, 30\right.$ seconds) steps were repeated for 40 cycles, flanked by a 10-minute denaturation and 5-minute elongation step. Data were analyzed by the $\Delta \Delta \mathrm{Ct}$ method. ${ }^{10}$

\section{Lung Tumor Tissue Collection}

Human lung tissue and corresponding clinical data were collected under a tissue banking protocol approved by the University of Colorado Institutional Review Board. Informed consent was obtained from each participant. The stage reported is the pathologic stage after surgical resection according to American Joint Committee on Cancer guidelines. Tumor samples and normal-appearing tissue from resected lobes were collected in RNALater (Qiagen). Complementary DNA and subsequent quantitative RT-PCR were prepared as described above.

\section{Statistical Analysis}

All data distributions were inspected before statistical analysis. The Student $t$ test was performed for 2-group comparisons, and the analysis of variance test was performed when comparing 3 or more groups. No multiple comparison was conducted. StatView version 5.0 was used for all statistical analysis (SAS Institute, Inc, Cary, NC). 
TABLE 1. Cell line characteristics

\begin{tabular}{lccccccc}
\hline Cell line & Tumor type & EGFR & K-ras & p53 & NF-kB with sPLA 2 inhibition & ERK 1/2 with sPLA inhibition & sPLA 2 \\
\hline SW1573 & BAC & WT & Mut & WT & Strong decrease & Strong increase \\
H2009 & Adenoca & WT & Mut & Mut & Decrease & Strong increase \\
H358 & BAC & WT & Mut & Mut & Decrease & Strong increase \\
A549 & Adenoca & WT & Mut & WT & Strong decrease & Dess \\
\hline
\end{tabular}

Strong attenuation of NF- $\kappa \mathrm{B}$ activity was correlated with WT p53. EGFR, Epidermal growth factor receptor; $N F-\kappa b$, nuclear factor kappa-b; $s P A_{2}$, secretory phospholipase $\mathrm{A}_{2} ; E R K$, extracellular signal-regulated kinase; $B A C$, bronchoalveolar carcinoma; WT, wild-type; Mut, mutant; Adenoca, adenocarcinoma.

\section{RESULTS}

\section{sPLA $_{2}$ IIa Expressed in K-ras Mutant Lung Cancer Cells}

Group IIa $\mathrm{SPLA}_{2}$ expression varies in K-ras mutant lung cancer cells. SW1573 and H2009 express more sPLA ${ }_{2} \mathrm{IIa}$ messenger RNA (mRNA) compared with H358 and A549 cells (Figure 1, A). Protein analysis by Western blot and immunofluorescence corroborate this finding (Figure 1, $B$ and $C$ ).

\section{Cell Survival in K-ras Mutant Lung Cancer Cells Depends on PPLA $_{2} \mathrm{IIa}$ Expression}

SPLA $_{2}$ IIa inhibition led to concentration-dependent apoptosis and cell death in all K-ras mutant lung cancer cells (Figure 2). Cells with higher baseline sPLA ${ }_{2}$ IIa were more susceptible to cell death with $\mathrm{SPLA}_{2} \mathrm{IIa}$ inhibition. Early apoptosis detected by annexin $\mathrm{V}$ staining after 8 hours of SPLA $_{2}$ IIa inhibition was increased in SW1573 and H2009 cells compared with H358 and A549 cells (Figure 2, A). The MTT assay confirmed concentrationdependent cell death after 24 hours of sPLA ${ }_{2}$ IIa inhibition, again with increased vulnerability in cells with higher sPLA $_{2}$ IIa expression (Figure 2, B).

\section{sPLA $A_{2}$ IIa Inhibition in K-ras Mutants Decreases NF- $\kappa$ B Phosphorylation}

Previous work has demonstrated that $\mathrm{SPLA}_{2} \mathrm{II}$ inhibition-associated apoptosis is related predominantly to decreased NF- $\kappa$ B activity. ${ }^{4}$ We confirmed that NF- $\kappa$ B phosphorylation is decreased with $\mathrm{SPLA}_{2} \mathrm{IIa}$ inhibition in
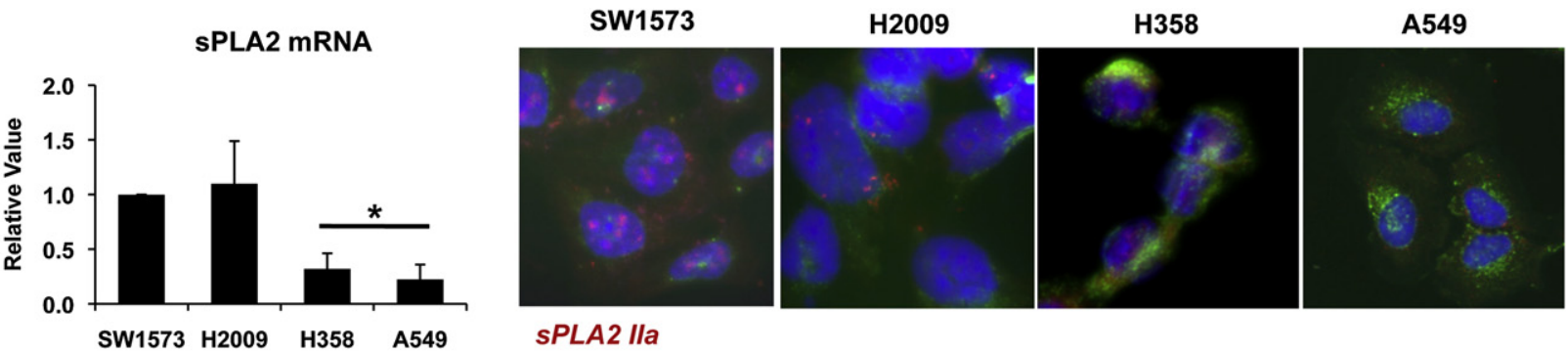

A
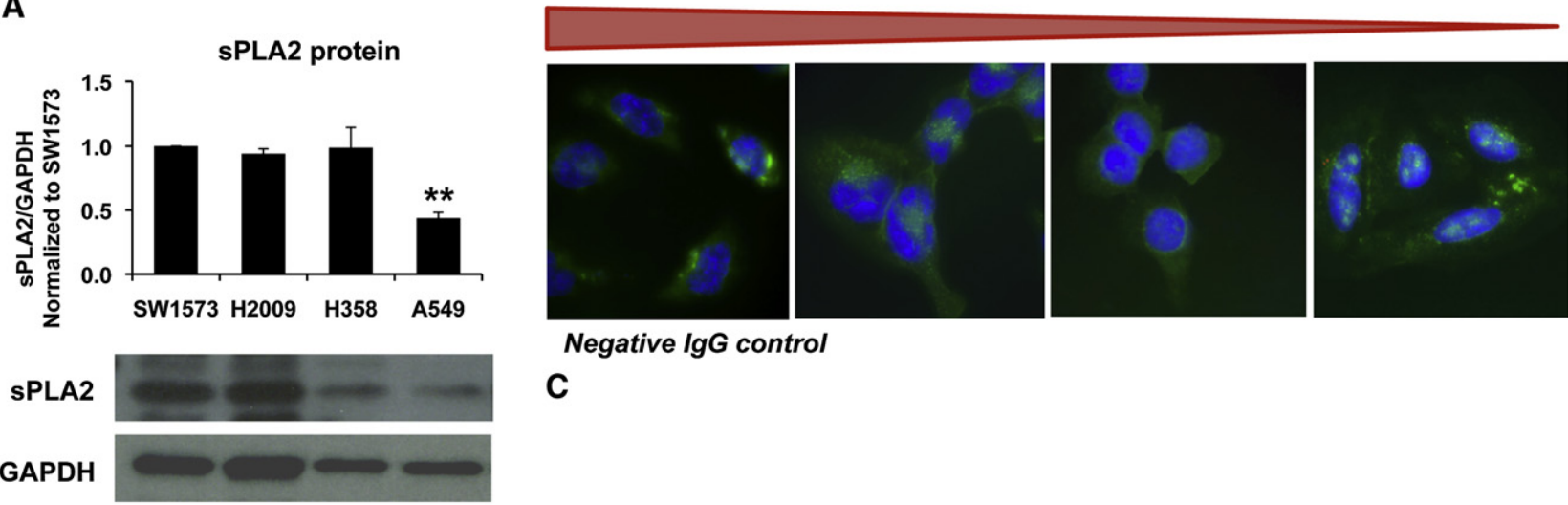

\section{Negative IgG control}

C

\section{B}

FIGURE 1. K-ras mutant lung cancer cell lines analyzed for baseline group IIa secretory phospholipase $\mathrm{A}_{2}$ ( $s P L A_{2} I I a$ ) expression. Expression varies with SW1573 and $\mathrm{H} 2009$ cells expressing more sPLA ${ }_{2}$ IIa compared with $\mathrm{H} 358$ and A549 cells. Messenger RNA ( $\left.m R N A\right)$ was evaluated by quantitative reversetranscription polymerase chain reaction $(R T-P C R)$, mean $\pm \mathrm{SEM}, * P<.05, \mathrm{n}=5$, run in triplicate $(\mathrm{A})$. sPLA ${ }_{2}$ IIa protein expression was evaluated by Western blot. Graph of densitometry, mean \pm SEM, $* * P<.005, \mathrm{n}=4$ (B). Immunofluorescence for sPLA $\mathrm{A}_{2} \mathrm{II}$ a was used for additional protein, $\mathrm{n}=3$ run in duplicate, $\mathrm{sPLA}_{2} \mathrm{IIa}=$ red, cell membrane = green, nuclei = blue (C). IgG, Immunoglobulin G; GAPDH, glyceraldehyde 3-phosphate dehydrogenase 

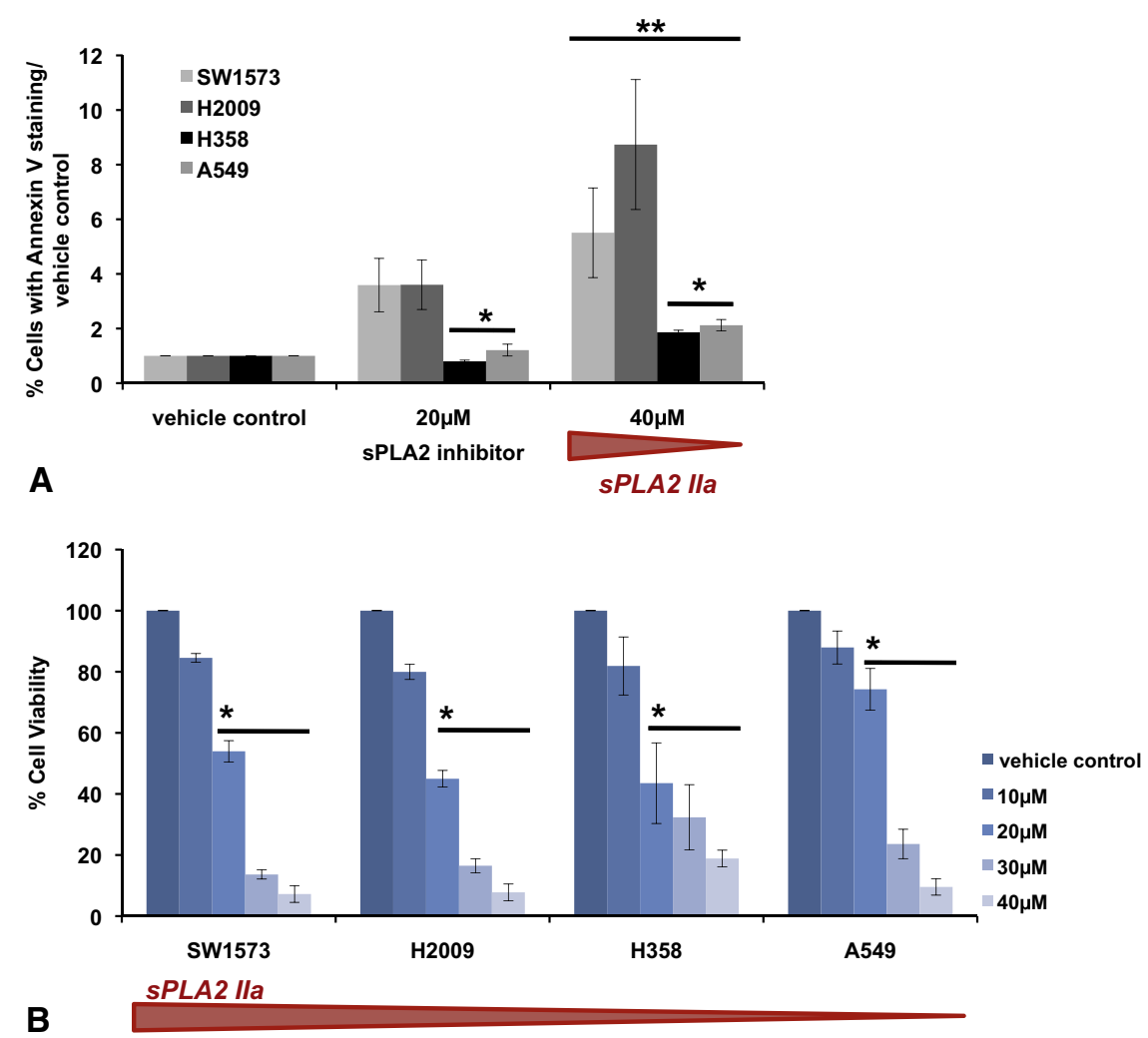

FIGURE 2. Group IIa secretory phospholipase $\mathrm{A}_{2}\left(s P L A_{2} I I a\right)$ expression inhibition promotes concentration-dependent apoptosis and cell death in lung cancer cell lines, and cytotoxicity of sPLA $\mathrm{A}_{2} \mathrm{II}$ inhibition parallels the level of sPLA 2 IIa expression. SW1573 and H2009 cells experience more apoptosis at 20 and $40 \mu \mathrm{mol} / \mathrm{L}$ compared with $\mathrm{H} 358$ and A549 cells. Percent of cells with annexin V staining were normalized to staining of the respective vehicle control, mean $\pm \mathrm{SEM}, * P<.03$ compared with SW1573, H2009. $* * P<.01$ compared with vehicle control, $\mathrm{n}=3-4$ (A). The 3-(4,5-dimethylthiazol-2-yl)2,5-diphenyltetrazolium bromide $(M T T)$ assay was used to assay cell viability after sPLA $\mathrm{A}_{2} \mathrm{IIa}$ inhibition. LD50 at 24 hours increases as sPLA $\mathrm{I}_{2} \mathrm{II}$ expression decreases, mean $\pm \mathrm{SEM}, * P<.003, \mathrm{n}=3$ run in triplicate $(\mathrm{B})$.

all K-ras mutant cells, whereas ERK $1 / 2$ phosphorylation increases in 3 cell lines but decreases in A549 cells (Figure 3). H2009 and H358 cells have a more modest decrease in NF- $\kappa$ B compared with SW1573 and A549 cells. H2009 and H358 cells are both p53 mutant.

\section{Human Lung Tumors Express $\mathrm{SPLA}_{2} \mathrm{IIa}$}

Fifteen lung tumors were examined for $\mathrm{SPLA}_{2} \mathrm{II}$ m mRA expression. One metastatic colon adenocarcinoma and 1 invasive esophageal adenocarcinoma were included in analysis for comparison. Lung tumors express detectable levels of sPLA $_{2}$ IIa mRNA (Figure 4). Although squamous and K-ras mutant tumors are less common in our cohort, there is a trend toward increased expression of $\mathrm{SPLA}_{2} \mathrm{II}$ in squamous tumors. In K-ras mutant tumors there is evidence of increased sPLA $_{2}$ IIIa expression with increasing stage. Both large cell neuroendocrine tumors express low levels of $\mathrm{SPLA}_{2} \mathrm{II}$.

\section{DISCUSSION}

This is the first study to specifically explore the role of sPLA $_{2} \mathrm{II}$ in K-ras mutant lung cancer. Consistent with our hypothesis, sPLA ${ }_{2} \mathrm{IIa}$ is a cytotoxic target in K-ras mutant lung cancer cells. Our finding that in vitro sensitivity to $\mathrm{SPLA}_{2} \mathrm{II}$ inhibition correlates with baseline sPLA $_{2}$ IIa expression, regardless of p53 mutation status, suggests that $\mathrm{SPLA}_{2} \mathrm{IIa}$ expression may predict response to $\mathrm{SPLA}_{2} \mathrm{II}$ in inhibition. Analysis of $\mathrm{SPLA}_{2} \mathrm{II}$ a expression in human lung tumors revealed some trends that we did not anticipate. Expression increases with cancer stage in $\mathrm{K}$-ras mutant tumors, but it does not necessarily increase with stage of non-small cell lung cancers overall. In addition, we found a trend of relatively high expression in squamous cell tumors, another subset of lung tumors that presently lacks targeted therapy. These findings are intriguing. Not only do they suggest that $\mathrm{sPLA}_{2} \mathrm{IIa}$ may be a more sensitive biomarker for a subset of tumors, but small molecule inhibitors to $\mathrm{SPLA}_{2} \mathrm{II}$ a have already been trialed for inflammatory disease,,$^{11}$ thus underscoring the possibility for rapid translational study in lung cancer.

Although $\mathrm{SPLA}_{2}$ inhibition significantly attenuated $\mathrm{NF}-\kappa \mathrm{B}$ activity in all lung cancer cell lines tested, cells 

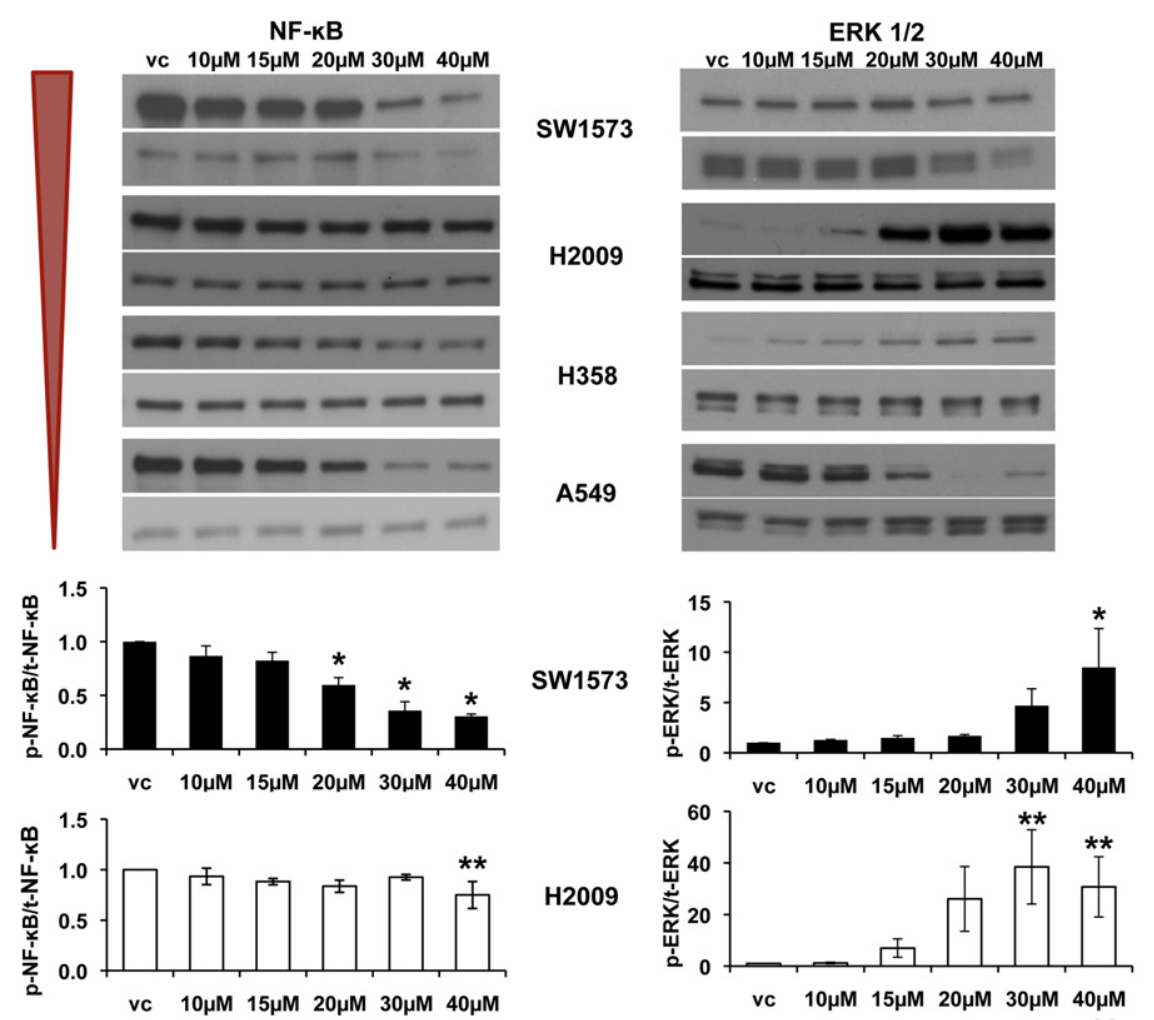

H2009
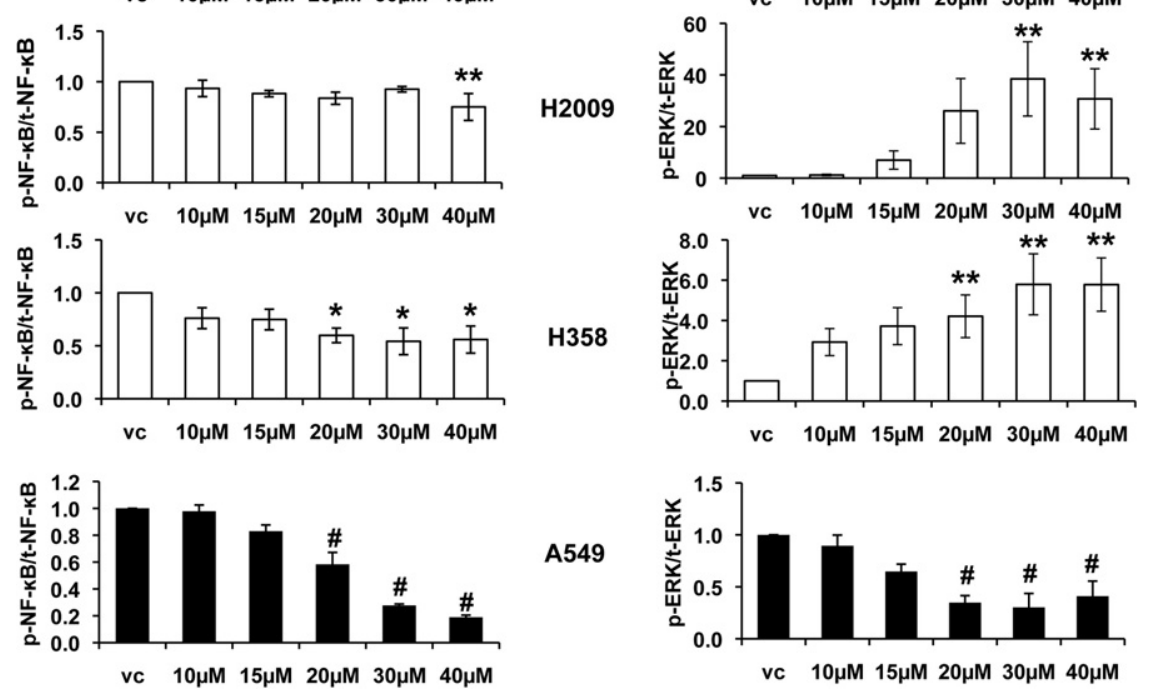

A549

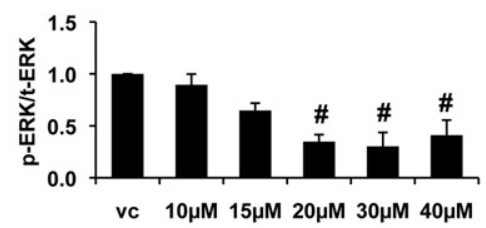

FIGURE 3. Group IIa secretory phospholipase $\mathrm{A}_{2}\left(s P L A_{2} I I a\right)$ inhibition attenuates nuclear factor kappa-b $(N F-\kappa B)$ activity in all cell lines, with a variable effect on extracellular signal-regulated kinase (ERK) $1 / 2$ activity. NF- $\kappa \mathrm{B}$ attenuation does not correlate with sPLA $\mathrm{A}_{2} \mathrm{II}$ expression level. Both $\mathrm{H} 2009$ and $\mathrm{H} 358$ (white bar graphs) are mutant p53 and demonstrate a more modest decrease in NF- $\kappa \mathrm{B}$ activity ( $v c$, vehicle control). Representative Western blots with corresponding densitometry, mean $\pm \mathrm{SEM}, * P<.05$, ** $P<.01$, $\# P<.001, \mathrm{n}=3-5$.

with mutant $\mathrm{p} 53$ had a less robust decrease in NF- $\kappa \mathrm{B}$ activity. Other investigators have demonstrated a relationship between mutant p53 and increased baseline NF- $\kappa \mathrm{B}$ activity. ${ }^{12,13}$ Our data corroborate this observation and further advance our understanding of the relationship between $\mathrm{sPLA}_{2} \mathrm{IIa}$ and NF- $\kappa \mathrm{B}$ by demonstrating that sPLA $_{2}$ IIa inhibition has a more modest effect on the activity of NF- $\kappa$ B in cancer cells where baseline activity is high. Additional studies are needed to determine whether this observation has implications for the effect of sPLA $_{2}$ IIa inhibition on downstream NF- $\kappa$ B targets such as metastasis-associated adhesion molecules and expression of inducible growth factors. ${ }^{5,14-17}$
An interesting and unexpected finding from our tumor analysis was that $\mathrm{sPLA}_{2}$ IIa expression was increased in squamous tumors. Kupert and associates ${ }^{3}$ recently published strong $\mathrm{SPLA}_{2}$ IIa protein staining in non-small cell lung tumor cores compared with normal lung tissue, including $100 \%$ of squamous cell tumor cores, although they did not quantify differences between histologic subtypes. ${ }^{3}$ This trend requires focused investigation of more squamous tumors inasmuch as there are currently no targeted therapies for this subset of non-small cell lung cancers. Furthermore, there is potential to examine the relationship between specific genetic alterations in squamous tumors and the tumor promoting activity of $\mathrm{SPLA}_{2} \mathrm{IIa}^{18}$ 
sPLA2 Ila mRNA Expression in Lung Tumors

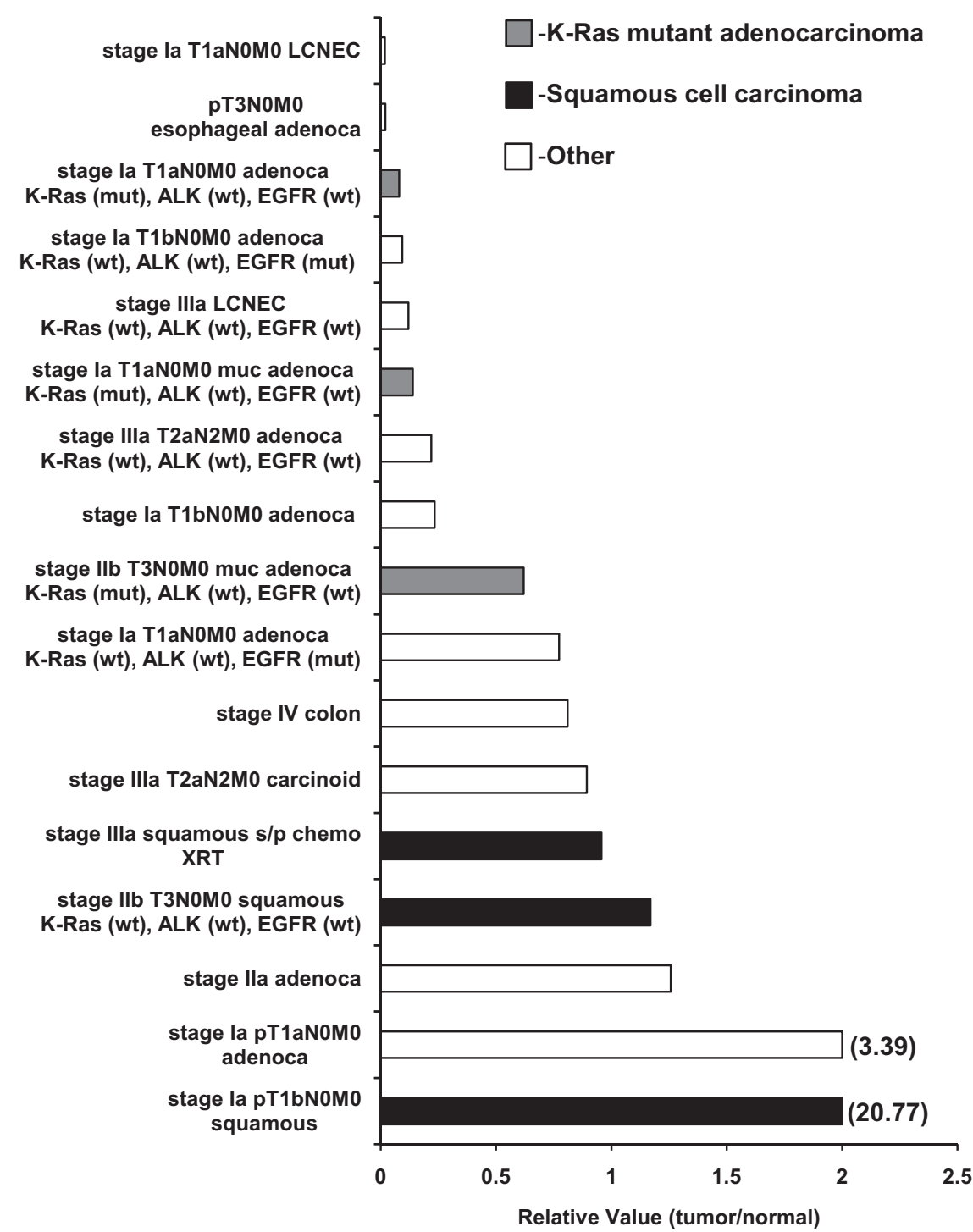

FIGURE 4. Human lung tumors express group IIa secretory phospholipase $\mathrm{A}_{2}\left(s P L A_{2} I I a\right)$. Primary lung tumors $(\mathrm{n}=15)$, invasive esophageal adenocarcinoma $(\mathrm{n}=1)$, lung metastasis from colon adenocarcinoma primary $(\mathrm{n}=1)$. K-ras mutant adenocarcinomas (gray) express increasing levels of sPLA $\mathrm{A}_{2} \mathrm{II}$ with increasing stage. Squamous cell carcinomas (black) express higher levels of sPLA 2 IIa. Samples that did not include K-ras, ALK, or epidermal growth factor receptor $(E G F R)$ mutant status indicate patients that did not consent to mutation analysis. Messenger RNA evaluated by quantitative reversetranscription polymerase chain reaction (RT-PCR), samples run in triplicate. LCNEC, Large cell neuroendocrine carcinoma; mut, mutant; wt, wild-type; $s / p$, status post; $X R T$, radiation therapy.

The pathways most frequently implicated in phospholipaserelated tumor growth are predominantly inflammatory, including NF- $\kappa \mathrm{B}$ and the arachidonic acid-eicosanoid pathway. ${ }^{14,19,20}$ Mechanistic investigation of how sPLA 2 IIa effects production of tumor-promoting eicosanoids, including its interactions with other phospholipase enzymes, is ongoing. In addition, sPLA $_{2}$ IIa is a secreted molecule with potential autocrine and paracrine signaling capability. ${ }^{21}$ Ongoing studies aim to clarify the effect of $\mathrm{sPLA}_{2}$ IIa inhibition on $\mathrm{SPLA}_{2} \mathrm{II}$ production and secretion with implications for understanding the role of $\mathrm{SPLA}_{2} \mathrm{IIa}$ in the tumor microenvironment to promote tumor progression and metastasis.

A limitation of this study is the use of a single small molecule inhibitor. We have previously presented comparable results with RNA interference of $\mathrm{SPLA}_{2} \mathrm{II}$, resulting in decreased tumor growth in an animal model. ${ }^{4}$ In addition, our tumor tissue analysis was limited owing to small sample size. Furthermore, we were only able to analyze mRNA secondary to the limited amount of tissue available to us. The analysis of RNA and protein in the lung cancer cell 
lines mostly demonstrates a parallel relationship between sPLA $_{2}$ IIa mRNA transcript and sPLA ${ }_{2}$ IIa protein expression. Future studies will need to include an analysis of protein expression of $\mathrm{SPLA}_{2} \mathrm{II}$ in tumors.

In summary, we have outlined the potential of $\mathrm{SPLA}_{2} \mathrm{IIa}$ as a global target for lung cancer therapy- $\mathrm{SPLA}_{2}$ inhibition is cytotoxic and potency correlates with baseline $\mathrm{SPLA}_{2}$ expression. Examination of human lung tumors suggests sPLA $_{2} \mathrm{II}$ has particular relevance for K-ras mutant and squamous cell tumors, 2 lung cancer subsets that presently pose therapeutic challenges. These data contribute to growing evidence of a role for $\mathrm{SPLA}_{2} \mathrm{II}$ in lung cancer that deserves further translational investigation.

\section{References}

1. Marks JL, Broderick S, Zhou Q, Chitale D, Li AR, Zakowski MF, et al. Prognostic and therapeutic implications of EGFR and KRAS mutations in resected lung adenocarcinoma. J Thorac Oncol. 2008;3:111-6.

2. Riely GJ, Marks J, Pao W. KRAS mutations in non-small cell lung cancer. Proc Am Thorac Soc. 2009;6:201-5.

3. Kupert E, Anderson M, Liu Y, Succop P, Levin L, Wang J, et al. Plasma secretory phospholipase A2-IIa as a potential biomarker for lung cancer patients with solitary pulmonary nodules. BMC Cancer. 2011;11:513-23.

4. Yu JA, MD, Mauchley D, Li H, Meng X, Nemenoff RA, Fullerton DA, Weyant MJ. Knockdown of secretory phospholipase A2 IIa reduces lung cancer growth in vitro and in vivo. J Thorac Cardiovasc Surg. 2012;144:1185-92.

5. Yu JA, Sadaria MR, Meng X, Mitra A, Ao L, Fullerton DA, et al. Lung cancer cell invasion and expression of intercellular adhesion molecule-1 (ICAM-1) are attenuated by secretory phospholipase $\mathrm{A}_{2}$ inhibition. J Thorac Cardiovasc Surg. 2012;143:405-11.

6. Downward J. Targeting RAS signaling pathways in cancer therapy. Nat Rev Cancer. 2003;3:11-22.

7. Heasley LE, Thaler S, Nicks M, Price B, Skorecki K, Nemenoff RA. Induction of cytosolic phospholipase A2 by oncogenic Ras in human non-small cell lung cancer. J Biol Chem. 1997;279:14501-4.

8. Wang XQ, Li H, Van Putten V, Winn RA, Heasley LE, Nemenoff RA. Oncogenic $\mathrm{K}$-Ras regulates proliferation and cell junctions in lung epithelial cells through induction of cyclooxygenase- 2 and activation of metalloproteinase-9. Mol Biol Cell. 2009;20:791-800

9. Mauchley D, Meng X, Johnson T, Fullerton DA, Weyant M. Modulation of growth in human esophageal adenocarcinoma cells by group IIa secretory phospholipase $A_{2}$. J Thorac Cardiovasc Surg. 2010;139:591-9.

10. Schmittgen TD, Livak KJ. Analyzing real-time PCR data by the comparative $\mathrm{C}_{\mathrm{T}}$ method. Nat Protoc. 2008;3:1101-8.

11. Bradley JD, Dmitrienko AA, Kivitz AJ, Gluck OS, Weaver AL, Wisenhutter C, et al. A randomized, double-blinded, placebo-controlled clinical trial of LY333013, a selective inhibitor of group II secretory phospholipase A2, in the treatment of rheumatoid arthritis. J Rheumatol. 2005;32:417-23.

12. Barbie DA, Tamayo P, Boehm JS, Kim SY, Moody SE, Dunn IF, et al. Systematic RNA interference reveals that oncogenic KRAS-driven cancers require TBK1. Nature. 2009;462:108-14.

13. Meylan E, Dooley AL, Feldser DM, Shen L, Turk E, Ouyang C, et al. Requirement of NF- $\kappa$ B signalling in a mouse model of lung adenocarcinoma. Nature. 2009;462:104-7.

14. Sadaria MR, Meng X, Fullerton DA, Reece TB, Shah RR, Grover FL, et al. Secretory phospholipase A2 inhibition attenuates intercellular adhesion molecule-1 expression in human esophageal adenocarcinoma cells. Ann Thorac Surg. 2011; 91:1539-45.

15. Blum R, Jacob-Hirsch J, Amariglio N, Rechavi G, Kloog Y. Ras inhibition in glioblastoma down-regulates hypoxia-inducible factor- $1 \alpha$, causing glycolysis shutdown and cell death. Cancer Res. 2005;65:999-1006.

16. Van Uden P, Kenneth NS, Rocha S. Regulation of hypoxia-inducible factor- $1 \alpha$ by NF- $\kappa$ B. Biochem J. 2008;412:477-84.

17. Granata F, Frattini A, Loffredo S, Staiano RI, Petraroli A, Ribatti D, et al. Production of vascular endothelial growth factors from human lung macrophages induced by group IIA and group X secreted phospholipases A2. J Immunol. 2010 184:5232-41.

18. Hammerman PS, Sos ML, Ramos AH, Xu C, Dutt A, Zhou W, et al. Mutations in the DDR2 kinase gene identify a novel therapeutic target in squamous cell lung cancer. Cancer Discov. 2011;1:78-89.

19. Dong Z, Liu Y, Scott KF, Levin L, Gaitonade K, Bracken RB, et al. Secretory phospholipase A2-IIa is involved in prostate cancer progression and may potentially serve as a biomarker for prostate cancer. Carcinogenesis. 2010;31:1948-55.

20. Krysan K, Reckamp KL, Dalwadi H, Sharma S, Rozengurt E, Dohaldwala M, et al. Prostaglandin E2 activates mitogen-activated protein kinase/Erk pathway signaling and cell proliferation in non-small cell lung cancer cells in an epidermal growth factor receptor-independent manner. Cancer Res. 2005;65:6275-81.

21. Hernández M, Martín R, García-Cubillas MD, Maeso-Hernández P, Nieto ML. Secreted PLA2 induces proliferation in astrocytoma through the EGF receptor: another inflammation-cancer link. Neuro Oncol. 2010;12:1014-23. 